\title{
Asthma does not increase COVID-19 mortality and poor outcomes: A systematic review and meta-analysis
}

\author{
Arto Yuwono Soeroto, ${ }^{1,2}$ Aga Purwiga, ${ }^{2}$ Emmy H. Pranggono, ${ }^{1,2}$ Rully M.A Roesli ${ }^{2}$
}

\begin{abstract}
Background: The Center for Disease Control and Prevention (CDC) has mentioned Coronavirus Disease 2019 (COVID-19) patients with moderate or severe asthma as a high risk group for severe illness. While WHO mentioned only chronic respiratory diseases, not specifically asthma as a risk factor for severe illness. There has been asthma prevalence discrepancy in studies of COVID-19 across the world.
\end{abstract}

Objective: This meta-analysis aims to investigate the association between asthma and composite poor outcome in patients with coronavirus disease (COVID-19).

Methods: We conducted a systematic literature search from PubMed and Embase database. We included all original research articles with adult COVID-19 patients > 18 years old and had information related to asthma as a risk factor. Studies with outcomes consisting of mortality, severe COVID-19, use of mechanical ventilation, ICU admission, and hospital admission were included in this study. The outcomes of interest were divided into severe COVID-19, mortality and other poor outcomes.

Results: Eleven studies were included in meta-analysis with a total of 6,046 patients. Asthma was not associated with composite poor outcomes with $\mathrm{OR}=0.92\left(95 \% \mathrm{CI} 0.71-1.19, p=0.61\right.$, and $\left.\mathrm{I}^{2}=8.49 \%\right)$. Furthermore, subgroup analysis showed that asthma was not associated with severe COVID $(p=0.76)$, mortality $(p=0.45)$, and other poor outcomes $(p=0.28)$.

Conclusion: Our study showed that asthma was not associated with severe COVID-19, mortality, and other poor outcomes in patients with COVID-19.

Key words: Asthma, Corticosteroid, COVID-19, mortality, poor outcome

\footnotetext{
From:

Division of Pulmonology and Critical Care Medicine, Department of Internal Medicine, Faculty of Medicine, Universitas Padjadjaran, Hasan Sadikin Hospital, Bandung, Indonesia Department of Internal Medicine, Faculty of Medicine,

Universitas Padjadjaran, Hasan Sadikin Hospital, Bandung, Indonesia
}

\author{
Corresponding author: \\ Arto Yuwono Soeroto \\ Division of Pulmonology and Critical Care Medicine, \\ Department of Internal Medicine, Faculty of Medicine, \\ Universitas Padjadjaran, Dr. Hasan Sadikin General Hospital, \\ Bandung 40161, Indonesia \\ E-mail: aysoeroto@yahoo.co.id
}

\section{Introduction}

Asthma is a routine part of general practice with more than five millions in the US prescribed treatments. ${ }^{1}$ The Center for Disease Control and Prevention (CDC) has mentioned Coronavirus Disease 2019 (COVID-19) patients with moderate or severe asthma as a high risk group for severe illness. ${ }^{2}$ While WHO mentioned only chronic respiratory diseases, not specifically asthma as a risk factor for severe illness. ${ }^{3}$ There has been asthma prevalence discrepancy in studies of COVID-19 across the world. Morbidity and Mortality Weekly Report (MWWR) by CDC stated that asthma was present in $17 \%$ hospitalized COVID-19 patients in Unites Stated (US). ${ }^{4}$ Interestingly, a study conducted in China by Zhang et al. reported that none of 140 COVID-19 patients had asthma. ${ }^{5}$ SARS-CoV-2 may have different mechanism than other respiratory viruses and contribute to this prevalence discrepancy. A study conducted by Van et al. shown bronchial asthma was one of the most common comorbids along with hypertension in Middle East Respiratory Syndrome (MERS) patients. ${ }^{6}$ However, the exact relationship is still unclear. 
Innate immune response to viral infection are characterized by production of type I (IFN- $\alpha$ or $\beta$ ) and type III Interferons (IFN- $\lambda$ ). Plasmacytoid dendritic cells (pDCs) are the predominant source of IFN- $\alpha$ produced in the peripheral blood during stimulation by viral infection. ${ }^{7}$ Airways epithelial cells in asthmatic patients show impaired production of IFN- $\alpha$. Therefore, the biased immune responses unable to prevent the spread of these virus to lower respiratory tract. ${ }^{8}$ Severe COVID-19 patients showed impaired IFN type 1 response characterized by low IFN- $\alpha$ production. ${ }^{9}$ Viral infections can also amplify allergic reactions through biased type $1 \mathrm{~T}$ helper $\left(\mathrm{Th}_{1}\right)$ and type $2 \mathrm{~T}$ helper $\left(\mathrm{Th}_{2}\right)$ immune responses. These findings suggest that asthmatic may be at high risk of severe COVID-19., ${ }^{7,810,11}$ We aimed to perform a systematic review and meta-analysis to investigate the association between asthma and composite poor outcomes in patients with COVID-19.

\section{Material and Methods \\ Study selection and eligibility criteria}

We included all original research articles with adult COVID-19 patients $>18$ years old and had information related to asthma as a risk factor. Studies with outcomes consisting of mortality, severe COVID-19, use of mechanical ventilation, ICU admission, and hospital admission were included in this study. The original research was not published in English language, not available in full text, with pediatric subjects $(<18$ years old), and case reports were excluded from this study. No ethical approval will be needed because data from previous published studies in which informed consent was obtained by primary investigators will be retrieved and analysed.

\section{Literature research}

We conducted a systematic literature research from PubMed and Embase database. We used keywords: (1) "COVID-19" OR "SARS-CoV-2" AND "Asthma", (2) "COVID-19" OR "SARS-CoV-2" AND "Characteristics", and (3) “COVID-19" OR "SARS-CoV-2" AND "Corticosteroids". We also performed hand searching and explored the queries through the references cited in some articles in order to include all relevant published articles. We conducted literature research from May $14^{\text {th }}$ and finalized on July $28^{\text {th }} 2020$. Duplicate results were removed. The remaining studies were screened for relevance by title and abstract. Further reading and investigation according to inclusion and exclusion was done to search potential relevance studies. The reporting of this systematic review and meta-analysis was conducted in accordance with the Preferred Reporting Items for Systematic Reviews and Meta-Analyses (PRISMA).

\section{Data extraction}

Data extraction was performed using standardized forms that include generic information (first author, year, place), sample size, study design, age, gender, and history of asthma. In addition, we also included information regarding asthma severity, asthma status (controlled, partly controlled, and not controlled), and use of inhaled corticosteroids if available. Data extraction was performed independently by two authors (AYS and P).

\section{Statistical analysis}

Stata version 16 was used for data collection and metaanalysis. Effect sizes for asthma as dichotomous outcomes (asthma and non-asthma) were calculated using restricted maximum likelihood with random effect model regardless of heterogeneity. Effect sizes were reported as odds ratio (OR) with its $95 \%$ confidence interval. Statistical significance was set at $\leq 0.05$ with a two-tailed hypothesis. Funnel plots drawn to evaluate the publication bias was conducted when there are at least 10 included studies. Further test for funnel plot asymmetry using Harbord's test were conducted when publication bias indicated. $P$-value $<0.05$ indicate no small study effect.

\section{Results Study Selection}

Initial search yielded 445 records from an electronic database and 15 records from hand-searching. Thirty-eight records were identified as duplicate. As much as 355 records were excluded after screening the title or abstract. After evaluating and assessing 67 potential studies, 11 studies were included. 56 studies were removed due to one of the following: outcome of interest not available, not available in English language. The selection process is shown in Figure 1.

\section{Study characteristics}

The basic characteristics of the study are shown in Table $\mathbf{1 .}$ There were a total of 6,046 patients from 11 studies. Asthma prevalence ranged from $0.9 \%$ to $15.8 \%$. Overall, male patients had a higher chance to get composite poor outcomes $(57.7 \%)$. Most study conducted outside China (90.9\%) which consist of Spain, Switzerland, US, Germany, Iran, and Mexico. However, none of the studies had information related to level of asthma severity, asthma control status, and use of inhaled corticosteroids.

\section{Asthma and composite poor outcome}

Meta-analysis conducted from 11 studies showed asthma was not associated with composite poor outcomes with $\mathrm{OR}=$ 0.92 (95\%CI $0.71-1.19, p=0.61$, and $\left.\mathrm{I}^{2}=8.49 \%\right)$. Due to limited number of study, use of mechanical ventilation, ARDS, hospital admission, ICU admission were grouped as other poor outcomes. Furthermore, subgroup analysis showed that asthma was not associated with severe COVID $(p=0.76)$, mortality $(p=0.45)$, and other poor outcomes $(p=0.28)$. The results of meta-analysis are summarized in Figure 2.

\section{Publication Bias}

Funnel plot graph in Figure 3 showed asymmetrical noninverted funnel that may indicate presence of publication bias. Therefore, Harbord's test was used to evaluate small study effect. Harbord's test showed $p=0.55$ that indicated there was no evidence of small study effect. 

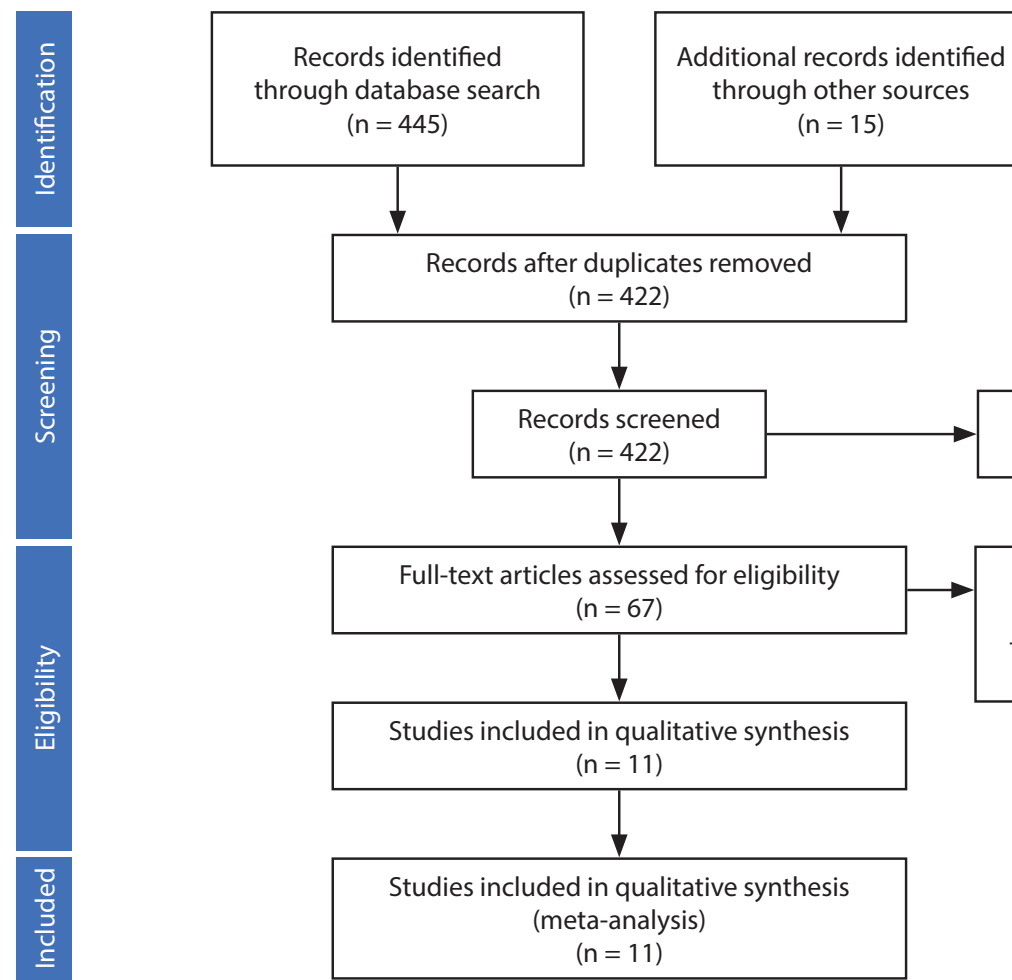

Records excluded $(n=355)$

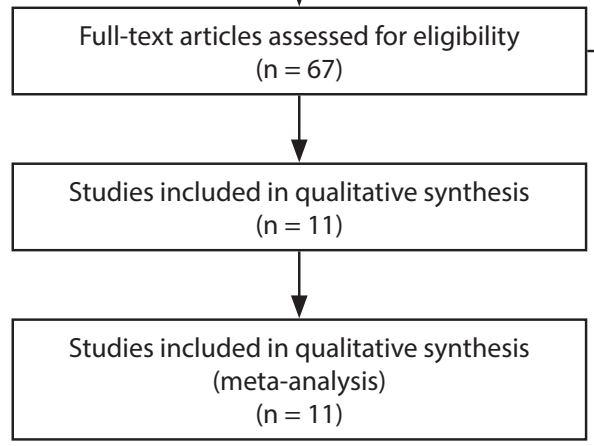

Figure 1.

Table 1. Characteristics of Included Studies.

\begin{tabular}{|c|c|c|c|c|c|c|c|}
\hline Authors & Study Design & Setting & Samples & $\begin{array}{c}\text { Age } \\
\text { (years, Median) }\end{array}$ & Male (\%) & Asthma (\%) & Measured Outcome \\
\hline Li X, $2020^{34}$ & $\begin{array}{l}\text { Observational } \\
\text { retrospective }\end{array}$ & China & $\begin{array}{c}548 \\
(269 \text { vs. } 279)\end{array}$ & $\begin{array}{c}60 \\
\text { (65 vs. } 56)\end{array}$ & $\begin{array}{c}50.9 \\
(56.9 \text { vs. } 45.2)\end{array}$ & $\begin{array}{c}0.9 \\
\text { (1.1 vs. } 0.7)\end{array}$ & Severe COVID-19 \\
\hline Borobia A, $2020^{35}$ & $\begin{array}{l}\text { Observational } \\
\text { prospective }\end{array}$ & Spain & $\begin{array}{c}2226 \\
(460 \text { vs. } 1766)\end{array}$ & $\begin{array}{c}61 \\
\text { (82 vs. } 56)\end{array}$ & $\begin{array}{c}48.2 \\
\text { (62.2 vs. } 44.6)\end{array}$ & $\begin{array}{c}5.2 \\
\text { (3.7 vs. } 5.5)\end{array}$ & Mortality \\
\hline Regina J, $2020^{36}$ & $\begin{array}{l}\text { Observational } \\
\text { retrospective }\end{array}$ & Switzerland & $\begin{array}{c}200 \\
(37 \text { vs. } 163)\end{array}$ & $\begin{array}{c}70 \\
(66 \text { vs. } 71)\end{array}$ & $\begin{array}{c}60 \\
\text { (78.4 vs. } 55.8)\end{array}$ & $\begin{array}{c}4 \\
(2.7 \text { vs. } 4.3)\end{array}$ & $\begin{array}{l}\text { Use of Mechanical } \\
\text { Ventilation }\end{array}$ \\
\hline Argenziano M, $2020^{37}$ & $\begin{array}{l}\text { Observational } \\
\text { retrospective }\end{array}$ & US & $\begin{array}{c}850 \\
(236 \text { vs. } 614)\end{array}$ & $\begin{array}{c}63 \\
(\mathrm{~N} / \mathrm{A})\end{array}$ & $\begin{array}{c}60.1 \\
(66.9 \text { vs. } 57.5)\end{array}$ & $\begin{array}{c}10.3 \\
\text { (12.3 vs. } 9.6)\end{array}$ & ICU Admission \\
\hline Paranjpe I, $2020^{38}$ & $\begin{array}{l}\text { Observational } \\
\text { retrospective }\end{array}$ & US & $\begin{array}{c}1078 \\
(310 \text { vs. } 678)\end{array}$ & $\begin{array}{c}65 \\
\text { (75 vs. } 57)\end{array}$ & $\begin{array}{c}58.1 \\
(61.6 \text { vs. } 58.5)\end{array}$ & $\begin{array}{c}7.79 \\
\text { (7.4 vs. } 7.9)\end{array}$ & Mortality \\
\hline Dreher M, $2020^{39}$ & $\begin{array}{l}\text { Observational } \\
\text { retrospective }\end{array}$ & Germany & $\begin{array}{c}50 \\
\text { (24 vs. } 26)\end{array}$ & $\begin{array}{c}65 \\
\text { (62 vs. } 68)\end{array}$ & $\begin{array}{c}66 \\
\text { (62 vs. } 69)\end{array}$ & 12 (17 vs. 8$)$ & ARDS \\
\hline Shahriarirad R, 2020 & $\begin{array}{l}\text { Observational } \\
\text { retrospective }\end{array}$ & Iran & $\begin{array}{c}113 \\
\text { (11 vs. } 102)\end{array}$ & $\begin{array}{c}53 \\
(\mathrm{~N} / \mathrm{A})\end{array}$ & $\begin{array}{c}62.8 \\
(63.6 \text { vs. } 62.7)\end{array}$ & $\begin{array}{c}6.2 \\
\text { (9.9 vs. } 5.8)\end{array}$ & Severe COVID-19 \\
\hline Shahriarirad R, 2020 & $\begin{array}{l}\text { Observational } \\
\text { retrospective }\end{array}$ & Iran & $\begin{array}{c}113 \\
\text { (11 vs. } 102)\end{array}$ & $\begin{array}{c}53 \\
(\mathrm{~N} / \mathrm{A})\end{array}$ & $\begin{array}{c}62.8 \\
(63.6 \text { vs. } 62.7)\end{array}$ & $\begin{array}{c}6.9 \\
\text { (11.1 vs. 5.7) }\end{array}$ & Mortality \\
\hline Suleyman G, 2020 & $\begin{array}{l}\text { Observational } \\
\text { retrospective }\end{array}$ & US & $\begin{array}{c}463 \\
(355 \text { vs. } 108)\end{array}$ & $\begin{array}{c}57.5 \\
(61.4 \text { vs. } 44.8)\end{array}$ & $\begin{array}{c}44.1 \\
(46.5 \text { vs. } 36.1)\end{array}$ & $\begin{array}{c}15.8 \\
(14.9 \text { vs. } 18.5)\end{array}$ & Hospital Admission \\
\hline Gregoriano, 2020 & $\begin{array}{l}\text { Observertional } \\
\text { retrospective }\end{array}$ & Switzerland & $\begin{array}{c}99 \\
\text { (35 vs. } 64)\end{array}$ & $\begin{array}{c}67 \\
\text { (69 vs. } 63.5)\end{array}$ & $\begin{array}{c}63 \\
\text { (80 vs. } 53 \text { ) }\end{array}$ & $\begin{array}{c}16 \\
\text { (14 vs. 17) }\end{array}$ & Severe COVID-19 \\
\hline Ortiz-Brizuella & $\begin{array}{l}\text { Observational } \\
\text { prospective }\end{array}$ & Mexiao & $\begin{array}{c}140 \\
\text { (29 vs. } 111)\end{array}$ & $\begin{array}{c}43 \\
\text { (49 vs. } 39)\end{array}$ & $\begin{array}{c}60.8 \\
(69 \text { vs. } 58.9)\end{array}$ & $\begin{array}{c}2.9 \\
(1.4 \text { vs. } 4.1)\end{array}$ & Hospital admission \\
\hline
\end{tabular}

Samples, age, male, and asthma were presented as total (positive outcomes vs. negative outcomes). US: United States; ICU: Intensive Care Unit; ARDS: Acute Respiratory Distress Syndrome; N/A: Not available 


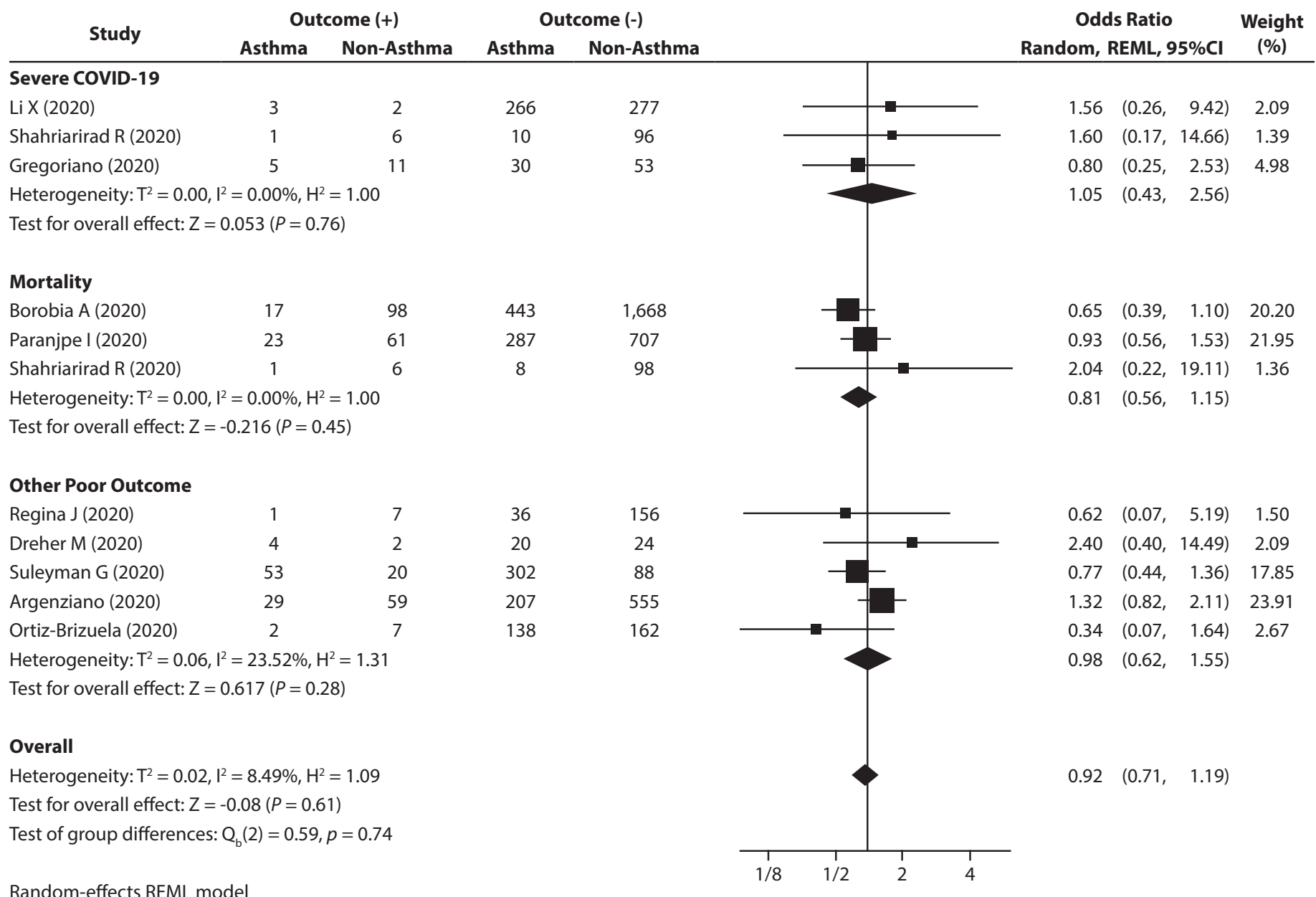

Figure 2.

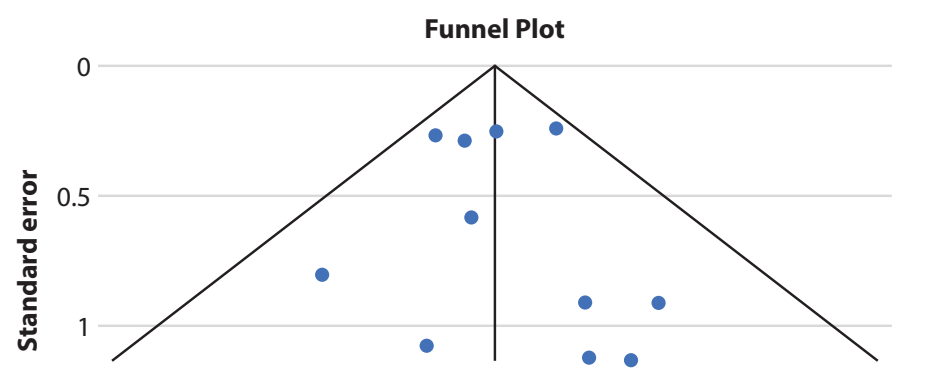

\section{Discussion}

This study showed asthma prevalence among COVID-19 cases ranged from $0.9 \%$ to $15.8 \%$. Some studies in China found that asthma prevalence was much lower compared to global estimates of prevalence in the general population. Zhang et al. reported none of 140 COVID-19 patients had asthma. ${ }^{12,13}$ Older age, diabetes, cardiovascular disease, and tobacco smoking have been identified as risk factor for severe COVID-19. ${ }^{14,15}$ Figure 2 showed that none of the studies have proven asthma to be a risk factor for mortality, severe COVID-19, and other poor outcomes.

Previous study showed allergy may increase the expression level of rhinovirus and influenza receptor, thus increases the risk of infection. ${ }^{11}$ SARS-CoV-2 may have different mechanism than other respiratory viruses. ${ }^{16,17}$ SARS-CoV-2 uses angiotensin-converting enzyme-2 (ACE2), a transmembrane protein expressed in the lungs and other tissues, as the main entry point into cells and the serine protease TMPRSS2 for priming spike virus (S) proteins. Significant reduction in ACE2 expression related to respiratory allergies and controlled allergen exposure are suggested as potential mechanism of decreasing the severity of COVID-19 in patients with respiratory allergies. ${ }^{18,19}$ Skewed $\mathrm{Th}_{2}$ may also be protective through down-regulation of hyper-inflammation associated with severe disease. ${ }^{7}$ 
Halpin et al. speculate that the therapy used by patients with chronic respiratory diseases such as inhaled corticosteroids, might at least partially prevent the development of severe SARS-CoV-2 infections. Inhaled corticosteroid administration is associated with lower ACE2 or TMPRSS2 gene expression in sputum from asthma patients. ${ }^{20}$ On the other hand, inhaled corticosteroids in asthmatic patients are associated with an increased risk of upper respiratory tract infection through innate immune responses impairment and viral clearance delays. ${ }^{21,22}$ Interferon responses to viral infections decrease in asthma patients. Thus, further inhibition by corticosteroids may lead to serious deterioration..$^{23}$ Some patients may develop severe COVID-19 characterized by a marked increase of pro-inflammatory cytokines known as cytokine storm. ${ }^{21}$ Nevertheless, the role of both systemic and inhaled corticosteroids in this condition is still not fully understood. ${ }^{23,24}$

ACE-2 expression in epithelial cells increases in COPD patients and also in smokers. ${ }^{25}$ Thus, COPD and current smokers are more susceptible to COVID-19. ${ }^{26}$ Since SARS-CoV-2 uses ACE-2 receptor for cell entry, we speculate that asthmatic patients and the use of inhaled corticosteroids may probably predispose to other viral infection but not SARS-CoV-2. This is logical, considering both asthma and COPD are chronic airway diseases but with different results in poor outcomes. That is, the attachment of SARS-CoV-2 to ACE-2 receptor is crucial for pathogenesis despite the immune response to viral infection decreases in asthmatic patients and inhaled corticosteroids use.

Special attention must be given to people with asthma. The Global Initiative for Asthma (GINA) does not recommend stopping oral corticosteroids in patients taking regularly for asthma treatments. Oral steroids can still be given to patients with moderate to severe exacerbations. ${ }^{27,28}$ Avoiding oral steroids during severe exacerbations may lead to serious complications. ${ }^{29}$ However, oral corticosteroids are not recommended in patients with COVID-19 lung disease. This is due to the possibility of increased viral replication..$^{28,30}$ Inhaled corticosteroid should be continued as needed or indicated. Stopping inhaled corticosteroids may lead to potentially dangerous worsening of asthma. ${ }^{29}$ Antihistamines and bronchodilators can be continued as indicated. Antibiotics are not routinely recommended in asthma exacerbations. ${ }^{1}$ Nebulizer should be avoided because of the risk of transmitting the virus to other patients and healthcare workers through aerosolization of the coronavirus. Pressurized metered-dose inhaler with spacer is preferred during asthma exacerbations. ${ }^{31,32}$ All methods for optimizing asthma control, whether inhaled steroids, inhaled steroid combinations plus long-acting bronchodilator therapy, or monoclonal antibody therapy, have shown to substantially reduce the risk of exacerbation which is mostly induced by virus, all standard asthma therapies must continue to be used to optimize asthma control, with the certainty that this will reduce the risk of adverse outcomes with COVID-19.28,10

It is important to note that early data in the US suggested a higher rate of asthma in patients hospitalized for severe COVID-19 illness, but did not specify whether asthma was allergic or not, an important differentiation that relates to our findings, nor the potential presence of other co-morbidities, such as obesity, that have been identified as risk factors for COVID-19 illness. Asthma is a chronic airway inflammation characterized by type 2 cytokines IL- 4 , IL- 5 , and IL-13. However, only half of patients have this feature. The remaining are type 2 low which has different immune features. ${ }^{33}$ Given the known heterogeneity in asthma, it is not surprising that reports on COVID-19 outcomes in relation to the disease have reported conflicting results.

\section{Conclusion}

This meta-analysis showed that asthma was not associated with severe COVID-19, mortality, and other poor outcomes (use of mechanical ventilation, ARDS, hospital admission, ICU admission). We encourage researchers to do further studies to investigate the role of asthma severity, symptom control status, and inhaled corticosteroid use in the association between asthma and COVID-19. However, regardless of asthma as a risk factor or not, optimal asthma treatment should be achieved at this pandemic.

\section{Limitations}

Some limitations should be noted. The funnel plot showed asymmetrical non-inverted funnel that may indicate presence of publication bias. The included studies diagnosed asthma only based on past history without knowing the severity, symptom control status, and medication use. Thus, it may not represent the intended phenomena of interest. In addition, inhaled corticosteroids may serve as confounding factor since it decreases ACE-2 receptor.

\section{Conflict of Interests}

The authors declare that there is no conflict of interests regarding the publication of this paper.

\section{Consent for Publication}

The authors declare that this manuscript is original, has not been published before and is not currently being considered for publication. All authors consent to the publication of this manuscript.

\section{Funding Statement}

The author(s) received no funding for this work.

\section{Ethics Approval}

Not applicable. No ethical approval will be needed because data from previous published studies in which informed consent was obtained by primary investigators will be retrieved and analysed.

\section{Competing Interest Statement}

The authors have declared that no competing interests exist.

\section{Acknowledgment}

- AYS, AP, EHP, and RMAR conceived and designed the study.

- AYS and AP acquired the data and performed the statistical analysis.

- All authors contributed to the writing of the manuscript. 


\section{References}

1. Beaney T, Salman D, Samee T, Mak V. Assessment and management of adults with asthma during the covid-19 pandemic. BMJ. 2020;369.

2. Centers for Disease Control and Prevention. People who are at higher risk for severe illness [Internet]. 2020 [cited 2020 Jun 22]. Available from: https:// www.cdc.gov/coronavirus/2019-ncov/need-extra-precautions/people -at-higher-risk.html.

3. World Health Organization. Prevention and control of NCDs at core of COVID-19 response [Internet]. 2020 [cited 2020 Jul 03]. Available from: https://www.euro.who.int/en/health-topics/noncommunicable-diseases/ chronic-respiratory-diseases/news/news/2020/6/prevention-and-control -of-ncds-at-core-of-covid-19-response.

4. Garg S, Kim L, Whitaker M, O'Halloran A, Cummings C, Holstein R, et al. Hospitalization rates and characteristics of patients hospitalized with laboratory-confirmed coronavirus disease 2019 - COVID-NET, 14 States, March 1-30, 2020. Morb Mortal Weekly Rep. 2020;69(15):485-64.

5. Zhang J, Li J, Su L, Yang J, Jiang X, Jiang N, et al. Clinical characteristics and risk factors of acute kidney injury in coronavirus disease 2019. Zhonghua Wei Zhong Bing Ji Jiu Yi Xue. 2020;32(4):407-11. Chinese.

6. Van Kerkhove MD, Alaswad S, Assiri A, Perera R, Peiris M, El Bushra HE, et al. Transmissibility of MERS-CoV Infection in Closed Setting, Riyadh, Saudi Arabia, 2015. Emerging infectious diseases. 2019;25(10):1802-9.

7. Carli G, Cecchi L, Stebbing J, Parronchi P, Farsi A. Is asthma protective against COVID-19? Allergy. 2020;10.1111/all.14426.

8. Edwards MR, Strong K, Cameron A, Walton RP, Jackson DJ, Johnston SL. Viral infections in allergy and immunology: how allergic inflammation influences viral infections and illness. J Allergy Clin Immunol.

9. Hadjadj J, Yatim N, Barnabei L, Corneau A, Boussier J, Smith N, et al. Impaired type I interferon activity and inflammatory responses in severe COVID-19 patients. Science. 2020;369:718-24.

10. Johnston SL. Asthma and COVID-19: is asthma a risk factor for severe outcomes? Allergy. 2020;75(7):1543-45.

11. Tantilipikorn P, Auewarakul P. Airway allergy and viral infection. Asian Pac J Allergy Immunol. 2011;29:113-9.

12. Li L, Zhang W, Hu Y, Tong X, Zheng S, Yang J, et al. Effect of Convalescent Plasma Therapy on Time to Clinical Improvement in Patients With Severe and Life-threatening COVID-19: A Randomized Clinical Trial. Jama. 2020;324(5):460-70.

13. Zhang JJ, Dong X, Cao YY, Yuan YD, Yang YB, Yan YQ, et al. Clinical characteristics of 140 patients infected with SARS-CoV-2 in Wuhan, China. Allergy. 2020;75(7):1730-41.

14. Zhou F, Yu T, Du R, Fan G, Liu Y, Liu Z, et al. Clinical course and risk factors for mortality of adult inpatients with COVID-19 in Wuhan, China: a retrospective cohort study. Lancet (London, England). 2020;395(10229): 1054-62.

15. Guo W, Li M, Dong Y, Zhou H, Zhang Z, Tian C, et al. Diabetes is a risk factor for the progression and prognosis of COVID-19. Diabetes Metab Res Rev. 2020:e3319.

16. Matsumoto K, Saito $H$. Does asthma affect morbidity or severity of Covid-19? J Allergy Clin Immunol. 2020;146(1):55-7.

17. Morais-Almeida M, Bousquet J. COVID-19 and asthma: To have or not to have T2 inflammation makes a difference? Pulmonology. 2020;26(5):261-3.

18. Kimura H, Francisco D, Conway M, Martinez FD, Vercelli D, Polverino F, et al. Type 2 inflammation modulates ACE2 and TMPRSS2 in airway epithelial cells. J Allergy Clin Immunol. 2020;146(1):80-8.e8.

19. Avdeev S, Moiseev S, Brovko M, Yavorovskiy A, Umbetova K, Akulkina $\mathrm{L}$, et al. Low prevalence of bronchial asthma and chronic obstructive lung disease among intensive care unit patients with COVID-19. Allergy. 2020: 10.1111/all.14420.

20. Halpin DMG, Faner R, Sibila O, Badia JR, Agusti A. Do chronic respiratory diseases or their treatment affect the risk of SARS-CoV-2 infection? Lancet Respir Med. 2020;8(5):436-8.
21. Halpin DMG, Singh D, Hadfield RM. Inhaled corticosteroids and COVID-19: a systematic review and clinical perspective. Eur Respir J. 2020.

22. Zhang W, Zhao Y, Zhang F, Wang Q, Li T, Liu Z, et al. The use of anti -inflammatory drugs in the treatment of people with severe coronavirus disease 2019 (COVID-19): The Perspectives of clinical immunologists from China. Clinical immunology (Orlando, Fla). 2020;214:108393.

23. Kumar K, Hinks TSC, Singanayagam A. Treatment of COVID-19 -exacerbated asthma: should systemic corticosteroids be used? Am J Physiol Lung Cell Mol Physiol. 2020;318(6):L1244-7.

24. Soy M, Keser G, Atagündüz P, Tabak F, Atagündüz I, Kayhan S. Cytokine storm in COVID-19: pathogenesis and overview of anti-inflammatory agents used in treatment. Clin Rheumatol. 2020;39(7):2085-94.

25. Leung JM, Yang CX, Sin DD. COVID-19 and nicotine as a mediator of ACE-2. Eur Respir J. 2020;55:2001261.

26. Leung JM, Yang CX, Tam A, Shaipanich T, Hackett TL, Singhera GK, et al. ACE-2 expression in the small airway epithelia of smokers and COPD patients: implications for COVID-19. Eur Respir J. 2020;55(5):2000688.

27. Global Initiative for Asthma. Global Strategy For Asthma Management and Prevention [Internet]. c2020 [cited 2020 Aug 20]. Available from: http:// www.ginasthma.org.

28. Abrams EM, Geert WJ, Yang CL. Asthma and COVID-19. CMAJ. 2020; 192(20):E551.

29. Bousquet J, Akdis C, Jutel M, Bachert C, Klimek L, Agache I, et al. Intranasal corticosteroids in allergic rhinitis in COVID-19 infected patients: An ARIA-EAACI statement. Allergy. 2020 Mar 31. doi: 10.1111/ all.14302. [Epub ahead of print].

30. Zha L, Li S, Pan L, Tefsen B, Li Y, French N, et al. Corticosteroid treatment of patients with coronavirus disease 2019 (COVID-19). Med J Aust. 2020;212(9):416-20.

31. Brough HA, Kalayci O, Sediva A, Untersmayr E, Munblit D, Rodriguez Del Rio $P$, et al. Managing childhood allergies and immunodeficiencies during respiratory virus epidemics - The 2020 COVID-19 pandemic: A statement from the EAACI-section on pediatrics. Pediatr Allergy Immunol. 2020 $10.1111 /$ pai.13262.

32. Levin M, Morais-Almeida M, Ansotegui IJ, Bernstein J, Chang YS, Chikhladze $\mathrm{M}$, et al. Acute asthma management during SARS-CoV2 -pandemic 2020. World Allergy Organ J. 2020;13(5):100125.

33. Lambrecht BN, Hammad H, Fahy JV. The Cytokines of Asthma. Immunity. 2019;50(4):975-91.

34. Belhadjer Z, Méot M, Bajolle F, Khraiche D, Legendre A, Abakka S, et al. Acute heart failure in multisystem inflammatory syndrome in children (MIS-C) in the context of global SARS-CoV-2 pandemic. Circulation. 2020 May 17. doi: 10.1161/CIRCULATIONAHA.120.048360. [Epub ahead of print].

35. Borobia AM, Carcas AJ, Arnalich F, Álvarez-Sala R, Monserrat-Villatoro J, Quintana M, et al. A Cohort of Patients with COVID-19 in a Major Teaching Hospital in Europe. J Clin Med. 2020;9(6).

36. Regina J, Papadimitriou-Olivgeris M, Burger R, Filippidis P, Tschopp J, Desgranges F, et al. Epidemiology, risk factors and clinical course of SARS-CoV-2 infected patients in a Swiss university hospital: an observational retrospective study. medRxiv [Preprint]. 2020 [Available from: https://www.medrxiv.org/content/10.1101/2020.05.11.20097741v1.

37. Argenziano MG, Bruce SL, Slater CL, Tiao JR, Baldwin MR, Barr RG, et al. Characterization and clinical course of 1000 Patients with COVID-19 in New York: retrospective case series. BMJ. 2020;369:m1996.

38. Paranjpe I, Russak A, De Freitas JK, Lala A, Miotto R, Vaid A, et al. Clinical Characteristics of Hospitalized Covid-19 Patients in New York City. medRxiv [Preprint]. 2020 [cited 2020 Jun 22]. Available from: https:// www.medrxiv.org/content/10.1101/2020.04.19.20062117v2.

39. Dreher M, Kersten A, Bickenbach J, Balfanz P, Hartmann B, Cornelissen C et al. The Characteristics of 50 Hospitalized COVID-19 Patients With and Without ARDS. Dtsch Arztebl Int. 2020;117(16):271-8. 